Cyrek M., Evaluation of sectoral advancement of EU countries in the face of the alternative competitiveness - social cohesion, „Ekonomia i Prawo. Economics and Law.”, Polszakiewicz B., Boehlke J. (ed.), Vol. 13, No. 2/2014, pp. 297-308. DOI: http://dx.doi.org/10.12775/EiP.2014.022.

\title{
EVALUATION OF SECTORAL ADVANCEMENT OF EU COUNTRIES IN THE FACE OF THE ALTERNATIVE COMPETITIVENESS - SOCIAL COHESION
}

\author{
SUMMARY
}

The study deals with a problem of inner consistency of aims of EU socio-economic policy, that often takes a form of the alternative: competitiveness - social cohesion. Criteria of political choice, which are not always revealed can lead to formulation of different recommendations and implementation of different solutions also concerning a field of sectoral policy.

In the background of the decisive problems, in the text were presented some alternative evaluations of sectoral development of EU-28 countries, which were prepared taking the assumptions of two variants of priorities found in the effectiveness aims or the social aims. There were presented two alternative rankings of countries which were worked out basing on Eurostat statistical data describing 2011 year. To reflect a sectoral advancement in a synthetic way in both cases there was used a method of development model basing on the Euclidian distance. In the first variant the choice of variables was dictated by their significant correlation with GDP per capita, in the second one with Gini coefficient. As a result there was verified a thesis about consistency of models of structural changes from the point of view of realizing aims of competitiveness and cohesion.

* Magdalena Cyrek, University of Rzeszów, Faculty of Economics, Department of Microeconomics, ul. M. Ćwiklińskiej 2, 35-601 Rzeszów, phone: +48 1787217 17, e-mail: mcyrek@ univ.rzeszow.pl. 
Results of the analyses indicate that better effects for integrated development can be found within the variant where the attention is focused on social aims. Such model of development is successfully realized by Scandinavian countries. An irrefutable role in modernization processes that favour reconciliation of competitiveness and social cohesion is played by knowledge-intensive sectors, especially of service character. Keywords: structural advancement, aims of developmental policy

JEL Classification: D63, I31, J21, L52, O11, O25

\section{INTRODUCTION}

A choice between competitiveness and social cohesion constitutes one of the unresolved dilemmas within a mainstream economics. In that context, in a very simplified way, competitiveness may be defined as a relative ability of a national economy to achieve high incomes ${ }^{1}$ by capturing maximal effectiveness of actions and productivity of resources. Social cohesion, within the indicated alternative, denotes for ensuring possibly fair distribution, that is identified with equity. Cohesion reflects a frontier level of socially and politically accepted divergences in social and economic welfare ${ }^{2}$.

Discussions about the alternative: competitiveness - cohesion (also specified as: efficiency - justice) prove the existence of numerous interrelations between economic growth and social inequalities. The most often used argument indicates that accumulation of resources constitutes a precondition to create modern, highly productive solutions that lead to maximization of output, while limiting participation in the results of undertaken actions has demotivating influence and minimize future inputs in searching for innovation. On the other hand, concentration of wealth leads to narrowing chances for development and potential usage of the poorest, what means irreversible losses in human capital and growing uncertainty of economic actions because of growing social tensions. Thus, existence of inequalities of both: frustrating and activating character ${ }^{3}$ results in ambiguous evaluation of the mentioned relations.

${ }^{1}$ B.L. Ślusarczyk, Determinanty międzynarodowej pozycji konkurencyjnej gospodarki polskiej w okresie transformacji, Wydawnictwo Uniwersytetu Rzeszowskiego, Rzeszów 2009, p. 15.

${ }^{2}$ A. Koźlak, Możliwości poprawy spójności terytorialnej UE w kontekście rozwoju sys-temów transportowych, [in:] M. Klamut, E. Szostak (eds), Jaka polityka spójności po roku 2013?, Prace Naukowe Uniwersytetu Ekonomicznego we Wrocławiu No. 95, Wydawnictwo Uniwersytetu Ekonomicznego we Wrocławiu, Wrocław 2010' p. 234.

${ }^{3}$ Such character of inequalities is appointed by M.G. Woźniak within a research program social inequalities - economic growth - modernization. Short presentation of the program 
While referring to the dilemma it is sometimes perceived as necessary to separate arguments concerning spheres of production and distribution. Rules about efficiency of production are different than the ones concerning participation in its results ${ }^{4}$. It seems, however, that separate analyses of productivity and distribution create just an introduction to deepened research on interrelations between them. The relations require to be identified concerning mechanism of interdependence and their results and, most of all, possibilities of interventions and shaping expected institutional solutions that are based in accepted ideology.

Besides, the problem of alternative competitiveness - cohesion is still unresolved taking into account both: theory as well as application of development policy. That is because it requires to make a choice between realizing actions directed at stimulation of effectiveness and growth of production or at support for distributional equity that assures higher social cohesion. Theoretical attitude of welfare economics refers to the Pareto efficiency rule, assuming efficiency and optimal income distribution. Unfortunately, market and government failures result in the fact that in practice often the real solution is the second best one, in which some compromise between effectiveness and equity is adopted 5 . G. Gerapetritis even discusses that a sharp division between stability/cohesion and growth/monetarism is one of the implications of economic default in Europe 6 .

Moreover, while development policy is realized there is very often made a mistake of an excess of competitive aims and a lack of their proper prioritizing. Such limitations are indicated e.g. concerning the Lisbon strategy (especially in its previous shape), in which an aspiration to be the most competitive economy (based on knowledge) coexisted with preservation of the existing social and economic structure. As a result the aims concerning increase in competitiveness were set against social aims ${ }^{7}$. Meanwhile, as M.G. Woźniak suggests, failing to consider interrelations between labour productivity and rules

is made in: Ł. Jabłoński, O nowym programie badawczym nad nierównościami spoteczno-ekonomicznymi, [in:] M.G. Woźniak (ed.), Nierówności spoteczne a wzrost gospodarczy. Kryzys finansów publicznych - przyczyny, implikacje, perspektywy spójności spoteczno-ekonomicznej, No. 31, Wydawnictwo Uniwersytetu Rzeszowskiego, Rzeszów 2013, p. 9.

${ }^{4}$ M. Leszczyńska, Zróżnicowanie dochodów ludności rolniczej i ich uwarunkowania, Wydawnictwo Uniwersytetu Rzeszowskiego, Rzeszów 2007, p. 44-51.

${ }^{5}$ Ibidem.

${ }^{6}$ G. Gerapetritis, Europe's new deal: a new version of an expiring deal, „European Journal of Law and Economics" Vol. 38/2014, p. 91-115.

${ }^{7} \mathrm{~K}$. Piech, Wiedza i innowacje w rozwoju gospodarczym: w kierunku pomiaru $i$ wspótczesnej roli państwa, Instytut Wiedzy i Innowacji, Warszawa 2009, p. 225-226. 
of distribution damages socio-economic cohesion, independently whether economic or social aims are preferred. Harmonizing economic efficiency and social justice requires to take an integrated approach, which adopts an interdisciplinary attitude and perceives all the complexity of human existence. The condition for resolving problems of socio-economic inconsistency is constituted not only by an allocation efficiency but, most of all, an adaptive efficiency and inclusive modernization ${ }^{8}$.

The issues of modernization favourable for combining competitiveness with cohesion are also of multidimensional character. It is indicated that a modern phase of development into a light economy described by declining role of manufacturing industry and emergence of a strong knowledge-intensive service sector leads to slow growth in advanced countries ${ }^{9}$. Simultaneously, structural changes into a knowledge-based economy are connected with increasing inequality in a form of skilled-unskilled wage gap, what is linked with liberalisation, mobility, sector-biased and factor-biased technological change or institutional reasons ${ }^{10}$. Moreover, transformation of the economic structure by sectors influences an income level and its distribution not only directly, through employment structures, sectoral wages and multiplier effect, but also indirectly through the family/household structures ${ }^{11}$. Nevertheless, one of basic aspects of modernization is shaping sectoral structures in a way that does not require adjudication between alternative aims but supports development in both fields: economic and social. Thus, the essential question is about a possibility to realize such rule in practice. This problem constitutes an object of the analyses presented in the study.

The aim of presented research is to evaluate structural development of EU countries. The assessment, however, will be presented in a variant way considering two criteria that are stated in the title alternative: competitiveness and social cohesion. To realize the task there will be constructed two synthetic indicators of sectoral advancement. A comparison of them, taking into account

${ }^{8}$ Woźniak M.G., Teoretyczne i praktyczne kwestie budowy spójności spoteczno-ekonomicznej dla gospodarki innowacyjnej, [in:] M.G. Woźniak (ed.), Gospodarka Polski 1990-2011. Tom 3. Droga do spójności spoteczno-ekonomicznej, Wydawnictwo Naukowe PWN, Warszawa 2012, p. 38-39, 49-51.

${ }^{9}$ C. Antonelli, C. Fassio, The economics of the light economy. Globalization, skill biased technological change and slow growth, „Technological Forecasting and Social Change” Vol. 87/2014, p. 89-107.

${ }^{10} \mathrm{~L}$. Pan, The impacts of education investment on skilled-unskilled wage inequality and economic development in developing countries, „Economic Modelling” Vol. 39/2014, p. 174-181.

${ }_{11}$ M. Iordana, M.N. Chilian, The sectoral structures in Romania, its regions and the EU countries - key features of economic and social cohesion, „Procedia Economics and Finance” Vol. 8/2014, p. 397-398. 
the assumed criteria, allows to answer a question about the possibility of realizing a postulate of harmonizing effectiveness and equity and to indicate the sectors that can help to fulfill this task.

\section{AGGREGATE MEASURE OF SECTORAL ADVANCEMENT FAVOURABLE FOR COMPETITIVENESS}

Competitiveness of EU countries in empirical research is most often reflected by GDP per capita created in the economy. Such results are strongly interdependent with numerous sectoral features, such as productive specialization and unique branch relationships. In modern postindustrial economies based on knowledge the indicators of structural advancement are constituted, first of all, by high shares in employment of service and knowledge-intensive branches. Most of them are strongly correlated with the final results of production activities, which are specified by GDP per capita ${ }^{12}$.

Alongside with the analysis of a role of specified sectors and branches for increasing competitiveness it is justified to evaluate in a synthetic way the level of sectoral advancement. The result of such assessment would indicate the system of structural features favourable for growth of production level and would enable identifying the most desired relations. Thus, in this part of the study an aggregate measure of sectoral advancement favourable for achieving high competitiveness of EU countries was constructed. To fulfill the task there were used data extracted from Eurostat database ${ }^{13}$. They were aggregated using a method of development model, thus creating basis to present ranking of the compared EU economies.

The initial range of information to be captured in the proposed indicator covered 13 variables, which were correlated at statistically significant level $(\alpha=0,05)$ with the level of GDP per capita in 2011 year. In such a way there was taken into account the basic criterion for the measure construction which is stimulation of competitiveness of the economies. The variables constituted percentage shares in total employment in 2011 year of following sectors:

12 A detailed discussion of such relations the author presents e.g. in the corresponding text: M. Cyrek, Sektorowe charakterystyki państw UE wobec alternatywy konkurencyjność - spójność spoteczna, [in:] M.G. Woźniak (ed.), Nierówności spoteczne a wzrost gospodarczy. Gospodarka Polski 1990-2013. Nadzieje i obawy o perspektywy zintegrowanego rozwoju, No.. 37(1/2014), Wydawnictwo Uniwersytetu Rzeszowskiego, Rzeszów 2014, p. 104-122.

13 Eurostat, http://epp.eurostat.ec.europa.eu (20.08.2013). 
- $X_{1}$ : Agriculture, forestry and fishing, mining and quarrying;

- $X_{2}$ : Manufacturing;

- $X_{3}$ : Services;

- $X_{4}$ : Low and medium low-technology manufacturing;

- $X_{5}$ : Total knowledge-intensive services (KIS);

- $X_{6}$ : Knowledge-intensive high-technology services;

- $X_{7}$ : Land transport, transport via pipelines, water transport, air transport, warehousing and support activities for transportation; travel agency, tour operator reservation services and related activities;

- $X_{8}$ : Information and communication;

- $X_{9}$ : Financial and insurance activities; real estate activities;

- $X_{10}$ : Professional, scientific and technical activities;

- $X_{11}$ : Public administration; activities of extraterritorial organisations and bodies;

- $X_{12}$ : Human health and social work activities;

- $X_{13}$ : Total knowledge-intensive activities (KIA).

All the variables were characterized by high international variability, excessing $10 \%$. From the next step of research there were, however, excluded these variables with high mutual correlation (excessing 0,9) as copying information. From the pair $X_{13}$ and $X_{5}$, the $X_{13}$ variable was eliminated as reflecting wider range of activities. Similarly, from the strongly correlated $X_{8}$ and $X_{6}$ pair of variables there was eliminated $X_{6}$ variable. Finally, to construct the synthetic indicator reflecting sectoral features favourable for achieving high competitiveness (understood as GDP per capita) there were used 11 variables. They were standardized. The next step, basing on the model method, was to choose some reference values of variables, that were accepted as the most desired from the point of view of the competitiveness aim. For the variables positively correlated with GDP per capita $\left(X_{3}, X_{5}, X_{8}, X_{9}, X_{10}, X_{11}, X_{12}\right)$ there were accepted maximum values of the variables, while for the variables negatively correlated with GDP per capita $\left(X_{1}, X_{3}, X_{4}, X_{7}\right)$ there were adopted minimum values. Basing on the Euclidian distance formula a synthetic value of the indicator of sectoral advancement favourable for competitiveness were counted for each countries. The value of the synthetic measure is incorporated within a range $\langle 0,1\rangle$. The ranking of EU countries was presented on figure 1 . 
Figure 1. Ranking of EU-28 countries basing on an aggregate measure of sectoral advancement favourable for competitiveness in 2011 year

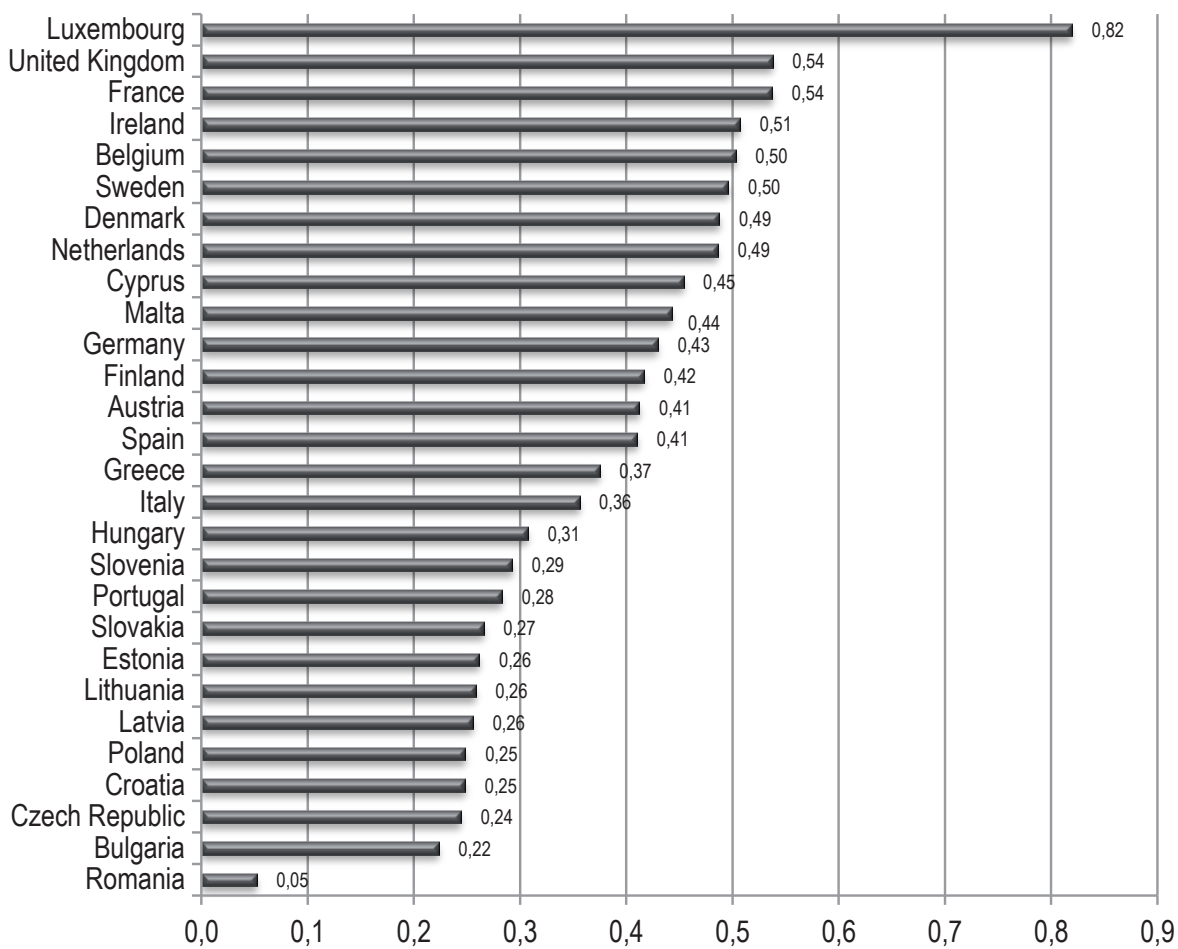

Source: own calculations based on data extracted from Eurostat, http://epp.eurostat.ec.europa.eu (20.08.2013).

Alongside with the adopted criterion, the presented synthetic indicator shows strong relations with the level of competitiveness specified by GDP per capita in 2011 year $(0,8991)$. There can also be observed strong consistency of rankings of EU countries basing on GDP per capita and the aggregate measure of sectoral advancement (rank correlation: 0,8659). Thus, taking into account competitiveness, the most favourable economic structures are characteristic for Luxembourg, United Kingdom and France. Unfavourable structural features can be observed in Romania, Bulgaria and the Czech Republic.

However, structural evaluation of the economies concerning competitiveness does not reflect any essential relations with a scale of social inequalities reflected by the value of Gini coefficient in 2011 year (correlation was -0,3401 and was not statistically significant; rank correlation was 0,3224 and also was not statistically significant). Sectoral features that contribute into high production do not directly influence income distribution in society, although the sign of the correlation suggests existence of some possibilities to avoid the necessity to make an alternative choice: competitiveness - equality. 


\section{AGGREGATE MEASURE OF SECTORAL ADVANCEMENT FAVOURABLE FOR SOCIAL COHESION}

Prioritizing aims of development that takes a direction at achieving better social cohesion instead of an absolute target of higher level of the average production indicates the necessity of taking different attitude to evaluation of sectoral advancement of EU countries. As a result it leads to adoption of different criteria of choice of variables which are to diagnose structural features. This approach suggests taking into account development of the branches which functioning can redeem social disproportions that appear because of inequalities in income distribution. It leads to choosing variables diagnosing structural advancement that are strongly connected with Gini coefficient ${ }^{14}$.

Adopting this criterion of evaluation of structural advancement, to construct a synthetic measure there were chosen the variables which are correlated at statistically significant level $(\alpha=0,05)$ with the scale of income inequalities. The variables constituted percentage shares in total employment in 2011 year of following sectors ${ }^{15}$ :

- $X_{1}$ : Agriculture, forestry and fishing; mining and quarrying,

- $X_{2}$ : High-technology sectors (high-technology manufacturing and knowledge-intensive high-technology services),

- $X_{3}$ : High and medium high-technology manufacturing,

- $X_{4}$ : Total knowledge-intensive services (KIS),

- $X_{5}$ : Knowledge-intensive high-technology services,

- $X_{6}$ : Total less knowledge-intensive services (LKIS),

- $X_{7}$ : Wholesale and retail trade; accomodation and food service activities; activities of households as employers,

- $X_{8}$ : Information and communication,

- $X_{9}$ : Professional, scientific and technical activities,

- $X_{10}$ : Human health and social work activities,

- $X_{11}$ : Total knowledge-intensive activities (KIA).

All the variables were characterized by variability between the EU countries excessing $10 \%$. However, to construct the synthetic indicator of sectoral advancement favourable for social cohesion there were used the variables which were characterized by mutual correlation underneath 0,9 . Thus, from pairs of variables $X_{11}-X_{4}$ and $X_{8}-X_{5}$ there were eliminated correspondingly $X_{11}$ and $X_{5}$. In the next step the variables were standardized and their ref-

${ }^{14}$ A detailed discussion of such relations the author presents e.g. in the corresponding text: M. Cyrek, op. cit., p. 104-122.

15 Eurostat, http://epp.eurostat.ec.europa.eu (20.08.2013). 
erence values were specified. As a model there were defined maximal value of the variables negatively correlated with Gini coefficient $\left(X_{2}, X_{3}, X_{4}, X_{8}, X_{9}\right.$, $\left.X_{10}\right)$ and minimal value of the variables of which high level occurred alongside with high income inequalities $\left(X_{1}, X_{6}, X_{7}\right)$. The last step was to calculate distance to the model using the Euclidian distance and then to construct the aggregate measure and present ranking of the EU countries (figure 2).

Figure 2. Ranking of EU-28 countries basing on an aggregate measure of sectoral advancement favourable for social cohesion in 2011 year

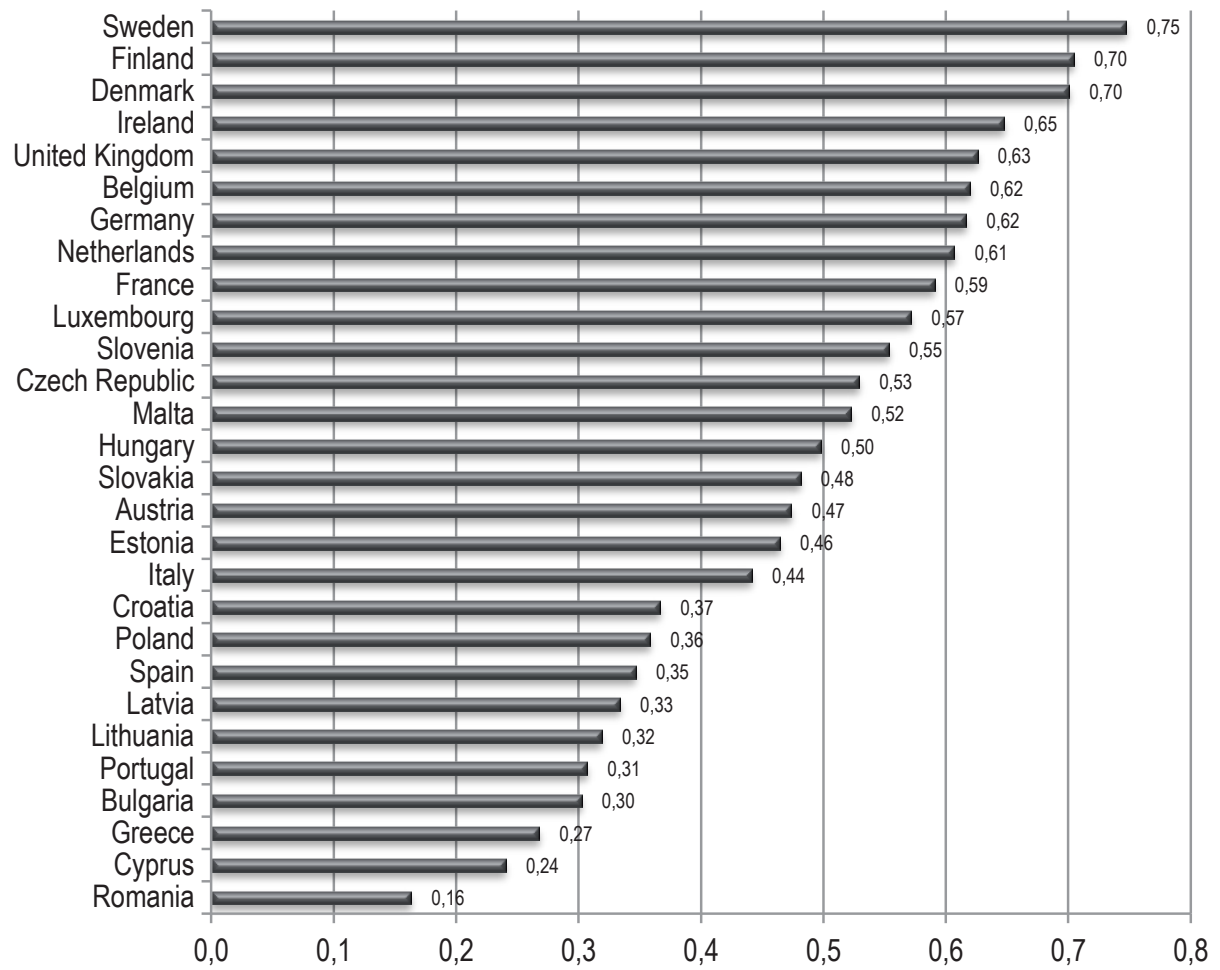

Source: own calculations based on data extracted from Eurostat, http://epp.eurostat.ec.europa.eu (20.08.2013).

The most advanced sectoral features favourable for social cohesion were observed in Scandinavian economies such as Sweden, Finland and Denmark. The countries are widely known as the ones realizing model of a welfare state. The least desired structural features taking into account egalitarian income distribution in society were characterizing Romania, Cyprus and Greece.

The presented above indicator of sectoral advancement appeared to be favorable not only from the point of view of redeeming social tensions having their roots in income distribution. It is correlated at statistically significant 
level with Gini coefficient $(-0,6695)$ and corresponding rankings of EU countries are also strongly consistent (rank correlation is 0,6508 ). It is also connected with the level of production per capita. The value of synthetic indicator of sectoral advancement is significantly correlated with the level of GDP per capita (0,5571), and the EU countries rankings basing on sectoral advancement and GDP per capita are also correlated (rank correlation is 0,7313). It means that an adequate structural system in economy can not only be related to better social cohesion but also to higher production level. Prioritizing aims of development into cohesion does not mean that it is necessary to resign from high level of GDP. Practical solutions in this field can be found in Scandinavian countries.

\section{CONCLUSIONS}

The conducted research indicates that the evaluation of sectoral advancement of economies can be done taking into account different criteria of not always consistent development aims. Economic efficiency and social cohesion constitutes such aims. Approaches to evaluate structures can thus be based on benefits which development of some specified branches brings for the level of production per capita or on benefits in a form of reduction of social tensions by supporting more equal income distribution. Identification of branches favourable for development concerns indication of fields favourable for competitiveness understood as GDP per capita level or such sectors that minimize level of income inequalities measured by Gini coefficient. Both attitudes often lead to different results and unfortunately are vulnerable to manipulation and abuse when criteria of choice are not revealed. Moreover to realize vision of integrated development it is necessary to simultaneously cover multidimensional relations: efficiency - justice - modernization.

In the study evaluation of structural features of the EU economies were done with the usage of two criteria and resulted in presentation of two rankings of the countries. The first one indicates that the sectoral structures which are the most favourable from the efficiency perspective characterize Luxembourg and next: the United Kingdom and France. The results of structural advancement are correlated with GDP per capita, however they are not essentially significant when considering Gini coefficient. The second ranking shows that the sectoral structures which are the most favourable from the social cohesion perspective describe Sweden and next: Finland and Denmark. The results are correlated with both Gini coefficient and GDP per capita as well. 
When taking the first approach by prioritizing pursuit to achieving high competitiveness understood as level of GDP per capita there were distinguished countries with such economic structures that are not directly connected with social cohesion. Such features can be perceived in the countries which realize economic policy based on liberal rules.

It appears, however, that adopting priorities in a form of creation of cohesive society does not exclude possibility of sectoral development that stimulates production level. In this variant competitiveness of aims of efficiency and equity is no longer a decisive problem. It seems then that the most desired model of structural development is realized by Scandinavian countries which successfully harmonize pursuits to increase competitiveness and support social cohesion.

It should be stated that modernization processes in the economies achieving the greatest socio-economic successes are connected with development of knowledge-intensive branches, especially within service sector. These are structural features of economies basing on usage of human capital, that combine social and efficiency functions of employment. Focusing sectoral policy of EU countries on these fields can constitute a base for integrated development.

\section{BIBLIOGRAPHY}

Antonelli C., Fassio C., The economics of the light economy. Globalization, skill biased technological change and slow growth, „Technological Forecasting and Social Change" Vol. 87/2014, http://dx.doi.org/10.1016/j.techfore.2013.11.006.

Cyrek M., Sektorowe charakterystyki panstw UE wobec alternatywy konkurencyjnośc spójność spoteczna, [in:] M.G. Woźniak (ed.), Nierówności spoteczne a wzrost gospodarczy. Gospodarka Polski 1990-2013. Nadzieje i obawy o perspektywy zintegrowanego rozwoju, No. 37(1/2014), Wydawnictwo Uniwersytetu Rzeszowskiego, Rzeszów 2014.

Eurostat, http://epp.eurostat.ec.europa.eu (20.08.2013).

Gerapetritis G., Europe's new deal: a new version of an expiring deal, „European Journal of Law and Economics", Vol. 38/2014, http://dx.doi.org/10.1007/s10657013-9422-z.

Iordana M., Chilian M.N., The sectoral structures in Romania, its regions and the EU countries - key features of economic and social cohesion, „Procedia Economics and Finance" Vol. 8/2014, http://dx.doi.org/10.1016/S2212-5671(14)00106-3.

Jabłoński Ł., O nowym programie badawczym nad nierównościami spoteczno-ekonomicznymi, [in:] M.G. Woźniak (ed.), Nierówności spoteczne a wzrost gospodarczy. Kry- 
zys finansów publicznych - przyczyny, implikacje, perspektywy spójności spoteczno-ekonomicznej, No. 31, Wydawnictwo Uniwersytetu Rzeszowskiego, Rzeszów 2013.

Koźlak A., Możliwości poprawy spójności terytorialnej UE w kontekście rozwoju systemów transportowych, [in:] M. Klamut, E. Szostak (eds), Jaka polityka spójności po roku 2013?, Prace Naukowe Uniwersytetu Ekonomicznego we Wrocławiu No. 95, Wydawnictwo Uniwersytetu Ekonomicznego we Wrocławiu, Wrocław 2010.

Leszczyńska M., Zróżnicowanie dochodów ludności rolniczej i ich uwarunkowania, Wydawnictwo Uniwersytetu Rzeszowskiego, Rzeszów 2007.

Pan L., The impacts of education investment on skilled-unskilled wage inequality and economic development in developing countries, „Economic Modelling” Vol. 39/2014, http://dx.doi.org/10.1016/j.econmod.2014.02.040.

Piech K., Wiedza i innowacje w rozwoju gospodarczym: w kierunku pomiaru i wspótczesnej roli państwa, Instytut Wiedzy i Innowacji, Warszawa 2009.

Ślusarczyk B.L., Determinanty międzynarodowej pozycji konkurencyjnej gospodarki polskiej w okresie transformacji, Wydawnictwo Uniwersytetu Rzeszowskiego, Rzeszów 2009.

Woźniak M.G., Teoretyczne i praktyczne kwestie budowy spójności spoteczno-ekonomicznej dla gospodarki innowacyjnej, [in:] M.G. Woźniak (ed.), Gospodarka Polski 19902011. Tom 3. Droga do spójności spoteczno-ekonomicznej, Wydawnictwo Naukowe PWN, Warszawa 2012. 